Nig. J. Biotech. Vol. 34 (2017) : 97-104

ISSN: 01891731

Available online at

http://www.ajol.info/index.php/njb/index

and www.biotechsocietynigeria.org

DOI: https://dx.doi.org/10.4314/njb.v34i1.13

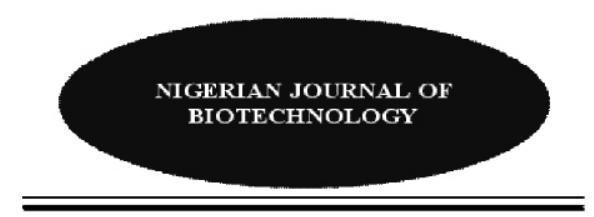

\title{
Association of IGF 1 gene polymorphisms with some morphometric traits of Nigerian indigenous sheep breeds
}

\author{
Raji, A. O. ${ }^{1}$, Mohammed, A. ${ }^{1}$, Igwebuike, J. U. ${ }^{1}$ and Alphonsus, C. $^{2}$ \\ ${ }^{1}$ Department of Animal Science, University of Maiduguri, Maiduguri, Borno state. \\ ${ }^{2}$ Department of Animal Science, Kaduna State University, Kafanchan Campus, Kaduna. \\ Copyright resides with the authors in terms of the Creative Commons License. 4.0. \\ See http://creativecommons.org/licenses/by/4.0/ \\ Condition of use: The user may copy, distribute, transmit and adapt the work, but must recognize the authors \\ and the Nigerian Journal of Biotechnology.
}

\section{Abstract}

The relationship between IGF 1 gene polymorphisms and some morphometric traits of the Balami, Uda and Yankasa sheep breeds of Nigeria was investigated. Blood samples and morphometric measurements were obtained from 150 sheep (50 for each of the three breeds) at the Maiduguri Livestock market and abattoir while DNA was extracted at the Biotechnology laboratory of the University of Maiduguri. Evaluation of results revealed 2 alleles (A and $B$ ) and 3 genotypes (AA, AB and BB) for all the breeds. The Uda and Yankasa breeds had higher frequency of allele $B(0.64$ and 0.56 , respectively) while Balami had higher allele frequency for $A(0.61)$. Balami and Yankasa had high heterozygosity for IGF-1 gene while Uda had high homozygosity for B. For Balami sheep, the genotype BB had higher $(P<0.05)$ body weight and heart girth $(56 \mathrm{~kg}$ and $79 \mathrm{~cm}$, respectively) than $A B$ for body weight $(45.80 \mathrm{~kg})$ and $B B$ for heart girth $(69.67 \mathrm{~cm})$. Conversely, genotype AA had higher body length $(94.33 \mathrm{~cm})$ than AB $(73.80 \mathrm{~cm})$. IGF 1 gene polymorphisms did not significantly $(P<0.05)$ affect most morphometric traits of the Yankasa and Uda sheep except height at withers where the genotype AB had higher $(P<0.05)$ height at withers $(71.77 \mathrm{~cm})$ than AA $(53.50 \mathrm{~cm})$ for Yankasa sheep. Thus, the three breeds were found to be $100 \%$ polymorphic at the regulatory region of IGF-1 locus and this gene may be used as a marker for some morphometric traits in Nigerian indigenous sheep.

Keywords: body weight, heart girth, height at withers, breeds, sheep

Correspondence author: razrajpearl@gmail.com

\section{Introduction}

The population of sheep in Nigeria is about 8 13.2 million and majority of them are found in the Northern region of the country (Bourn et. al., 1986). There are four major breeds of sheep in Nigeria with the Balami, Uda and Yankasa breeds being wide spread in the Northern region of the country and the WAD in the South. Sheep have characteristic features that make them survive by enabling them to tolerate the peculiarities of their environment (humid or arid). For example, they have long legs to walk long distances in search of food and water in arid environments (Yunusa et. al., 2013).

The growth of any organism is under the influence of factors such as genotype, hormones and nutrition in a complex interaction. Sheep that grows fast; breeds early, produce more lambs and reach market weight early, ensuring quicker returns to the farmer (Akinyemi and Salako, 2012). In order to maximise production in animal breeding, selection for improvement is a very important strategy. However, the design of such improvement programmes requires genetic parameter estimates which are necessary to predict genetic gains. Rashidi et. al. (2008) observed that, selection must be based on genetic merit instead of phenotype for genetic progress because factors such as age, sex and, type and year of birth influence their estimation. 
Insulin-like growth factor I (somatomedin C) is a candidate gene located in the euchromatin region of chromosome 3 . Because of its involvement in the expression of complex traits, the association of this gene polymorphisms with economically important traits in farm animals have been investigated (Rothschild and Soller, 1997). Growth, skeletal and immune function traits and their association with IGF 1 gene have been examined using this approach in sheep (Adam and Maddox, 1993; He et. al., 2003; Bahrami et. al., 2013). Insulin-like growth factor I gene plays an important role in childhood growth and stimulates skeletal growth, cell differentiation and metabolism in adults. IGF-1 also functions in the regulation of cell growth and development especially in nerve cells, skeletal muscle, cartilage, bone, liver, kidney, nerves skin, hematopoietic cell and lungs as well as cellular DNA synthesis (Sakowaski et. al., 2009; Sattler, 2013). Thus, IGF-1 gene is considered to be a candidate gene for predicting growth and meat quality traits in animal genetic improvement schemes (Machado et. al., 2003; Andrade et. al., 2008). Several reproductive traits (duration of pregnancy, twin ovulations and pre-implantation embryo development) have also been associated with IGF-1 gene in cattle (Sirotkin et. al., 2003; Echternkamp et. al., 2000; Velazquez et. al., 2005). IGF-1 might be a strong candidate gene for reproductive traits as well.

Some methods such as Restricted Fragment Length Polymorphism (RFLP), Amplified fragment length polymorphisms (AFLP), Random Amplification of Polymorphic DNA (RAPD) and Simple Sequence Repeat (SSR) are used to study the genome or phylogenetics of animals. In addition, genetic maps of any animal being studied can be created using some of these methods. Genomic response to selection may also be measured in livestock using genetic markers. Thus, selected and non-selected livestock may be differentiated by presence of different alleles due to a distorted segregation at the genetic markers (Maheswaran, 2014).

The gene for Insulin-like Growth Factor 1 (IGF1) may play important roles in the growth of multiple tissues, including mammalian muscle.
Therefore, it has been proposed as a candidate gene for growth traits in farm animals as it could be used in Marker-Assisted-Selection (Honarvar et. al., 2012). IGF-I intron-2 polymorphisms was found to correlate positively with the twinning rate (Kim et. al., 2009). The association of IGF-I gene polymorphisms (5'-flanking region) with birth and weaning weight was reported by Li et. al. (2004). However, Curi et. al. (2004) found no such association.

The aim of this study was to identify IGF 1 gene polymorphisms by PCR-RFLP and evaluate the association between these polymorphisms and morphometric traits of some Nigerian indigenous sheep breeds.

\section{Materials and Methods}

The blood samples and morphometric traits for the study were obtained at the Maiduguri livestock market and blood samples were analysed at the Biotechnology Centre, University of Maiduguri. Maiduguri, the Borno State capital is located on Latitude $11^{\circ} 52 \mathrm{~N}$ and Longitude $13^{\circ} 14 \mathrm{E}$ of the Equator. It occupies an area of about 3,000 km ${ }^{2}$, and is the largest town in NorthEastern Nigeria. The weather condition of the area, for most part of the year, is hot and dry with short raining season in the months of June to September. The soil of the study area is generally sandy-loam.

Maiduguri lies in the Sahel ecological zone, characterized by few trees and vast grassland. The grasses are seasonal and disappears during the dry season. The agricultural activities in the area include arable farming, livestock farming, fishing and hunting. Other major activities in the area, include, trading and weaving of caps.

Blood samples for DNA extraction, were collected from a total of one hundred and fifty (150) adult sheep through the jugular vein, using needle and syringe $(5 \mathrm{ml})$ and preserved in EDTA bottles. Fifty (50) each of Balami, Uda and Yankasa sheep, were randomly sampled. The samples were conveyed to the Biotechnology Centre, University of Maiduguri inside a cooler with ice pack. 
Standard kit (Promega, UK) was employed in extracting genomic DNA from the sheep blood samples. Polymerase Chain Reaction was carried out on $50 \mu$ volume containing approximately $1.0 \mu \mathrm{l}$ of $0.2 \mu \mathrm{M}$ each of primer (Table 1$) .10 \mu \mathrm{l}$ of 5X GoTaq colourless buffer, $5 \mu$ of 25 $\mathrm{Mmol} / \mathrm{MgCl}_{2}, 1.0 \mu \mathrm{l}$ of $10 \mu \mathrm{M}$ each of dNTPs, $2 \mu \mathrm{l}$ of $50 \mu \mathrm{M} / \mu \mathrm{l}$ GoTaq polymerase (Promega USA) and $29.25 \mu \mathrm{l}$ nuclease free water. PCR condition were as follows; initial denaturation of $95^{\circ} \mathrm{C}$ for 5 minutes, followed by 35 cycles of denaturation at $95^{\circ} \mathrm{C}$ for 60 seconds, annealing between 55 and $60^{\circ} \mathrm{C}$ for 30 seconds, extension at $72^{\circ} \mathrm{C}$ for 60 seconds, with final extension at $72^{\circ} \mathrm{C}$ for 5 minutes on Master cycler (Eppendorf AG.2233, Hamburg Germany).

RLFP analysis was performed by incubating a mixture of $5 \mu \mathrm{L}$ of regulatory region of PCR product, $16.3 \mu \mathrm{L}$ of distilled water, $2.5 \mu \mathrm{L}$ of enzymes buffer and $1.2 \mu \mathrm{L}$ of Hae II/BSP 143 II (New England Biolabs, Berverly, M.A. USA) at $37^{\circ} \mathrm{C}$ for 3 hours inside a water bath, allowing the restriction enzymes to cut, at its restriction sites. A $1 \%$ agarose was prepared by weighing $1 \mathrm{~g}$ of agarose powder and dissolved in $100 \mathrm{ml}$ of $1 \mathrm{X}$ TAE buffer then swirled to ensure thorough mixing. The dissolved agarose is microwaved for about 3-4 minutes and allowed to cool to about $60{ }^{\circ} \mathrm{C}$. Ethidium bromide $(10 \mu \mathrm{L})$ was added and mixed avoiding bubbles. The gel cassette was assembled and the gel, poured in to the gel trough. The gel comb was inserted and left to set for about 30 minutes. 1X TAE buffer was poured into the electrophoresis tank till it fills up. The gel comb was removed carefully from the solidified agarose, and the side rubber seal dissembled.

The set agarose gel was transferred to the gel tank, ensuring the buffer floods at least $2 \mathrm{~mm}$ above the gel. The comb grooves were labeled according to the samples, to identify the lines on the gel photograph. Loading dye $(2 \mu \mathrm{L})$ and $5 \mu \mathrm{L}$ of PCR amplicons transferred on to a spread sheet of parafilm $M$ then mixed using $10 \mu \mathrm{l}$ pipette and the mixture transferred to the gel well. The gel tank was closed and power cords connected. Power pack was switched on and the gel allowed to run for 30 minutes at $120 \mathrm{~V}$. The progress of the gel was monitored by reference to the marker dye. The resulting amplified bands were visualized with UV transilluminator (CSLMICRODUC System Cleaver Scientific UK) fitted with camera (Canon power short GI2 UK).

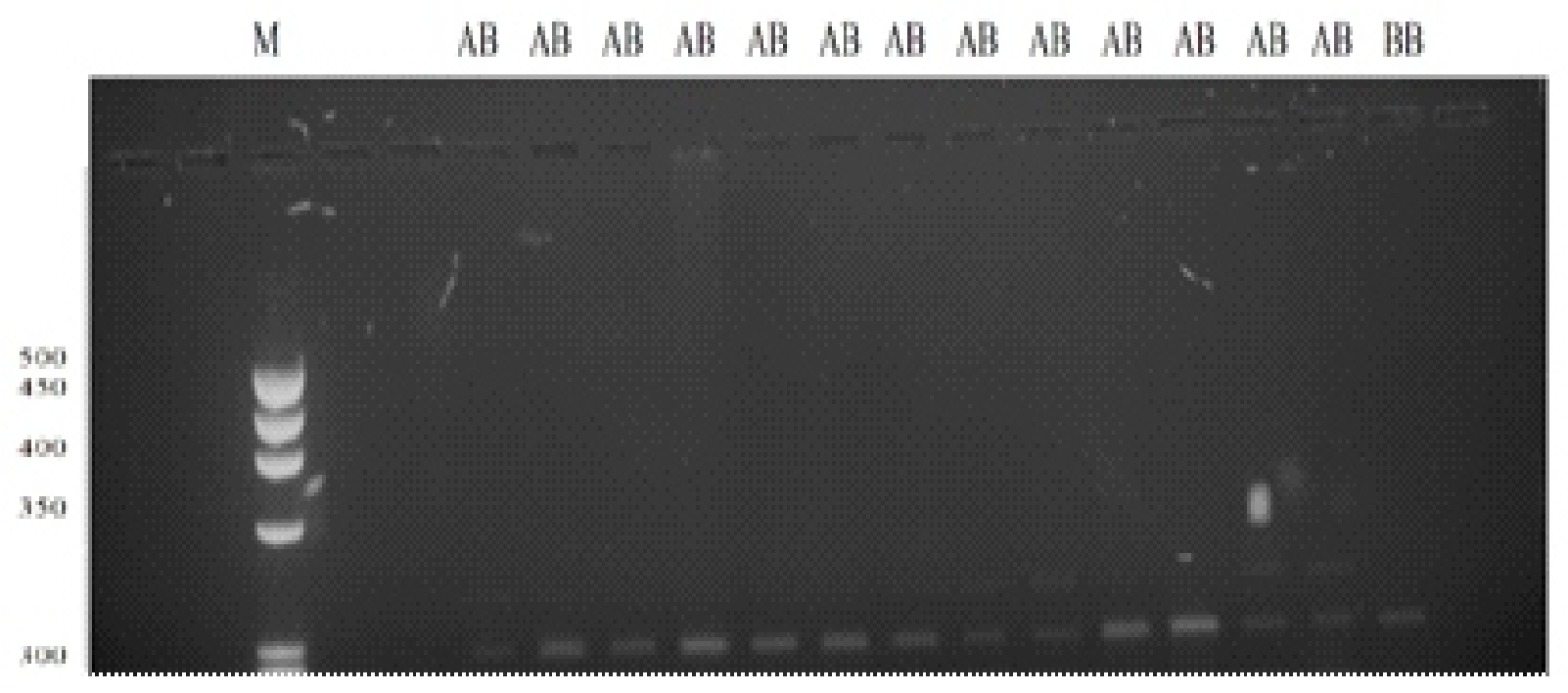

Plate 1. Yankasa sheep 


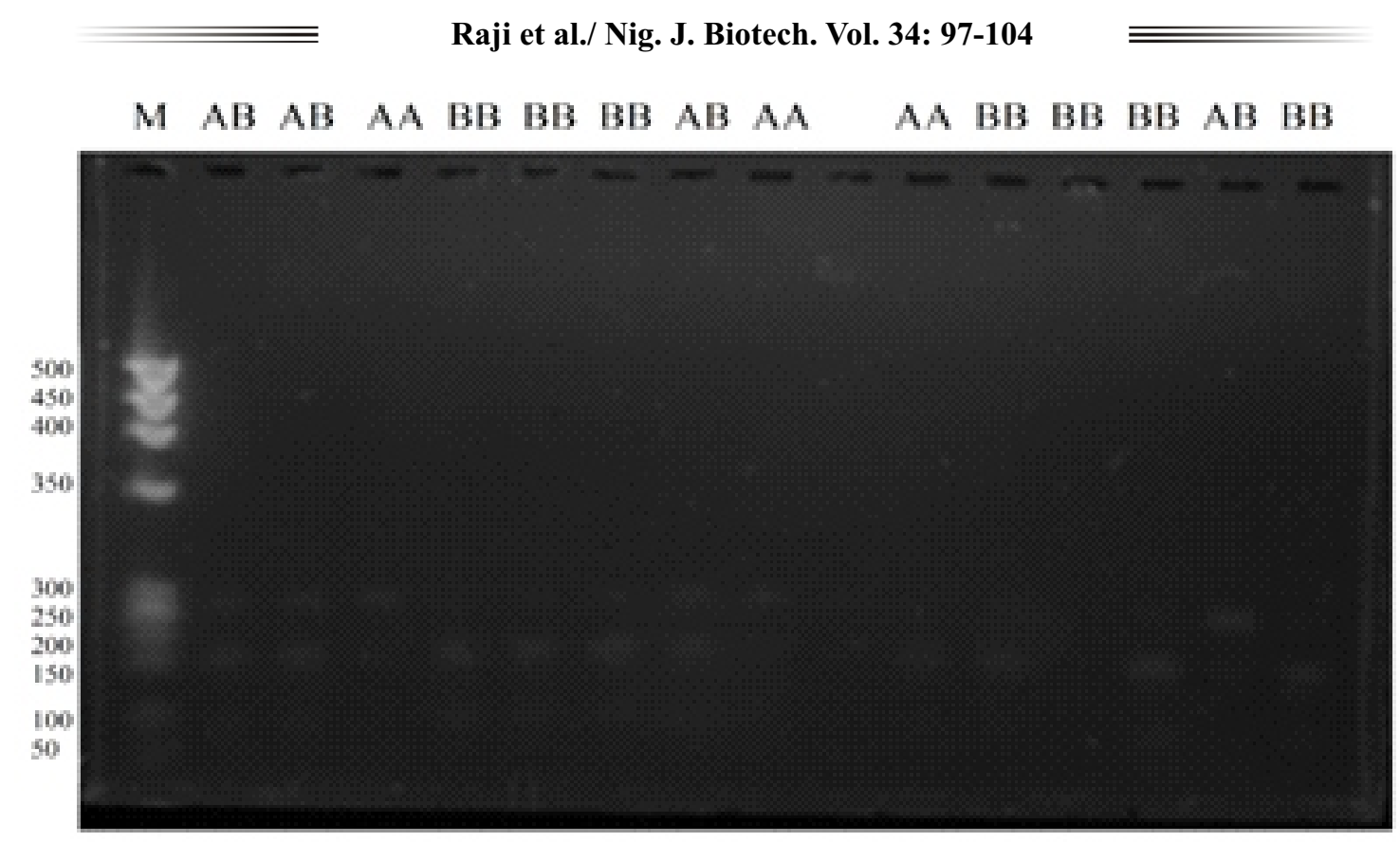

Plate 2. Genetic Profile for Uda Sheep

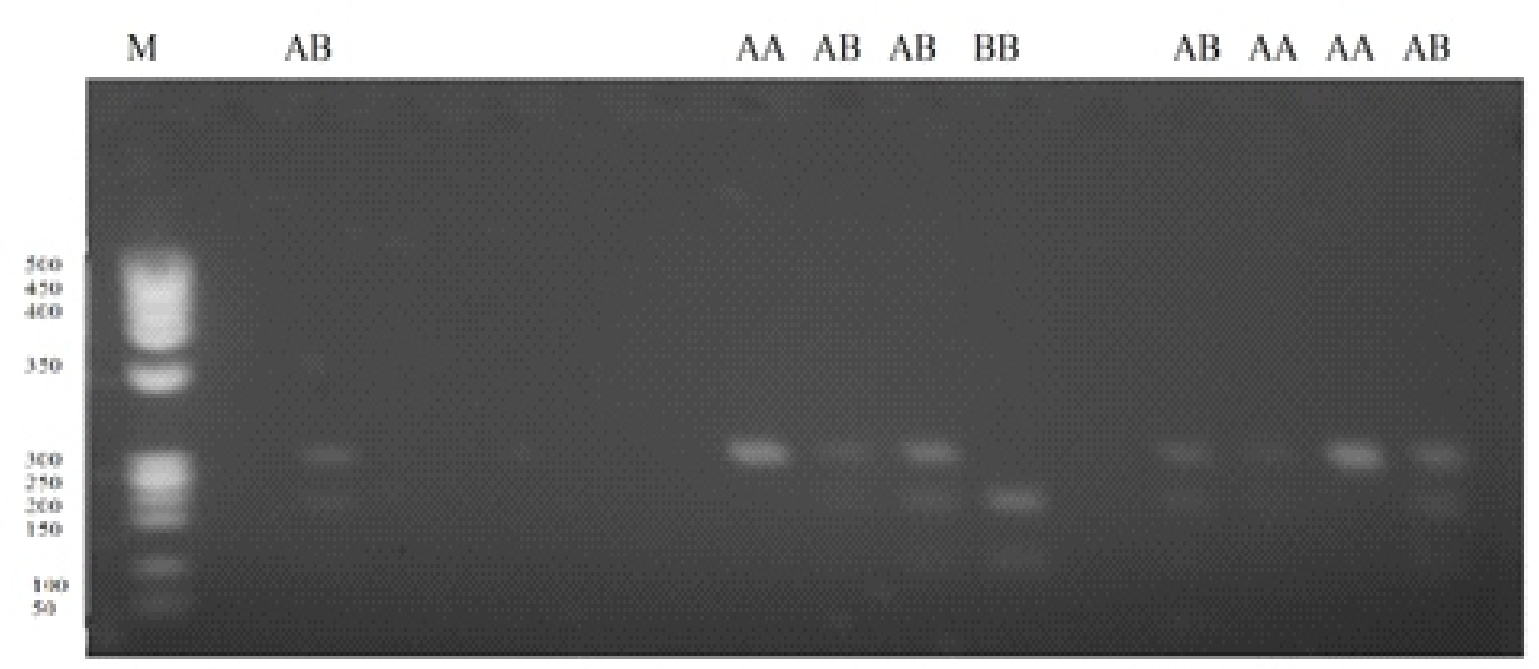

Plate 3. Genetic Profile for Balami Sheep

Table 1: Primers used to amplify sheep genomic DNA for IG

-1 gene analysis.

\section{Product size}

$\begin{array}{lll}\text { Primer } & \text { AT }\left({ }^{\circ} \mathrm{C}\right) & \text { Bp }\end{array}$

5 regulatory region

F: TGAGGGAGCCAATTACAAAGC

R: CCGGGCATGAAGACACACACAT

55

294

Exon 1

F: TCACTGTCACTECTAAATTCAG

R:CTTCAGAAATCACAAAAGAGCAC

60

228 
The morphometric traits were measured thus:

Body Weight (BW): The weight of sheep was taken using a hanging weighing balance and the reading taken when the animal had stopped moving.

Height at withers (HW): This was measured as the distance from the ground to the points of the withers with a measuring stick graduated in centimeters.

Body length (BL): This was measured as the distance from the occipital protuberance to the base of the tail. It was measured with a measuring tape $(\mathrm{cm})$.

Heart girth (HG): This was measured as the narrowest circumference immediately posterior to the front legs with a measuring tape.

The procedure used for the analysis of the association between IGF-1 polymorphisms and morphometric traits was the General Linear Model of the statistical package SPSS, with the following model:

$Y_{i j}=\mu+G_{i}+\varepsilon_{i j}$

where $Y_{i j}=$ dependent variable; $\mu=$ general mean; $\mathrm{Gi}=$ effect of the i-th genotype of IGF1 $(A A, A B, B B)$ and $\varepsilon i j=$ random error. Significant means were compared by the Least Significant Difference method in the same statistical package.

\section{Results and Discussion}

The genotype and allele frequencies of the three sheep breeds are presented in Table 2 . Evaluation of results revealed 2 alleles and 3 genotypes for all the breeds (Plates 1, 2 and 3). The alleles were $A$ and $B$ and genotypes $A A, A B$ and $\mathrm{BB}$. Thus, the three breeds were found to be $100 \%$ polymorphic with two different alleles in the 5 'regulatory region of IGF-1 locus and monomorphic in exon 1 for the population.
However, Hajihosseinlo et. al. (2013) reported polymorphisms of IGF 1 gene at exon 1 in Makui sheep and Kim et. al. (2009) in intron 2. This inconsistency may be due to breed differences. The Uda and Yankasa had high frequency of allele B (0.64 and 0.56, respectively) while Balami had high allele frequency for $A(0.61)$. Bahrami et. al. (2013) observed high allele frequency for $A$ in a study on Mehraban sheep though the authors used the SSCP variant of IGF1. The frequencies of the genotypes are: Balami; $A A(0.33), A B(0.56)$ and $B B(0.11) ;$ Uda; $A A$ (0.21), $A B(0.29)$, and $B B(0.50)$ and Yankasa; $A A(0.21), A B(0.46)$ and $B B(0.33)$. The allelic frequencies are Balami $A(0.61)$ and $B(0.39)$, Uda $A(0.36)$ and $B(0.64)$ and Yankasa A (0.44) and $B(0.56)$. Balami and Yankasa had similar patterns of genotype distribution while that of Uda was different. Balami and Yankasa had high heterozygosity for IGF-1 gene while Uda had high homozygosity for B. He et. al. (2012) and Bahrami et.. al. (2013) also observed three genotypes ( $A A, A B$ and $B B$ ) in Mehraban sheep in Hamedan Province, Iran and Chinese sheep (small tail Han, Hu, Texel and Dorset ewes). However, the genotype frequencies observed by He et. al. (2012) and Bahrami et. al. (2013) were different from those recorded in this study as their results indicated higher homozygosity for $A A$. This may be due to difference in breeds. Genetic variation describes naturally occurring genetic differences among individuals of the same species. This variation permits flexibility and survival of a population in the face of changing environmental circumstances. Consequently, genetic variation is often considered an advantage, as it prepares the breed or species for the unexpected.

Table 2: Genotypeand Allele Frequencies of IGF

-1 in Nigerian Sheep

Breed Loas AA AB BB A B

\begin{tabular}{llllllll}
\hline Balami & IGF & -1 & 0.33 & 0.56 & 0.11 & 0.61 & 0.39
\end{tabular}

$\begin{array}{llllllll}\text { Udda } & \text { IGF } & -1 & 0.21 & 0.29 & 0.50 & 0.36 & 0.64\end{array}$

$\begin{array}{lllllll}\text { Yankasa IGF } & -1 & 0.21 & 0.46 & 0.33 & 0.44 & 0.56\end{array}$ 
The Effects of IGF 1 gene polymorphisms on morphometric traits of the Balami sheep are presented on Table 3. IGF 1 gene polymorphisms significantly $(P<0.05)$ affected most morphometric traits of the Balami sheep except height at withers. The genotype BB had higher (P $<0.05$ ) body weight and heart girth (56 kg and $79 \mathrm{~cm}$, respectively) than $A B$ for body weight $(45.80 \mathrm{~kg})$ and BB for heart girth $(69.67 \mathrm{~cm})$. Conversely, genotype AA had higher body length
$(94.33 \mathrm{~cm})$ than $A B(73.80 \mathrm{~cm})$. It is not surprising that genotype $\mathrm{BB}$ with a higher heart girth measurement also had a higher body weight. This may be due to the fact that heart girth is a measure of condition and higher heart girth measurements usually translates to a higher body weight. The result also showed that all genotypes did not differ in height due to nonsignificant genotype effect on height at withers.

Table 3: Effects of IGF 1 gene polymorphisms on morphometric traits of the Balami sheep

\begin{tabular}{|c|c|c|c|c|c|c|c|}
\hline \multirow[b]{2}{*}{ Morphometric traits } & \multirow[b]{2}{*}{ Overall mean } & \multirow[b]{2}{*}{ AA } & & \multicolumn{2}{|c|}{ Genotype } & \multirow{2}{*}{\multicolumn{2}{|c|}{ BB }} \\
\hline & & & & $\mathbf{A B}$ & & & \\
\hline Body Length (cm) & $82.00 \pm 6.21$ & $94.33 \pm 5.97$ & $a$ & $73.80 \pm 4.62$ & $\mathrm{~b}$ & $86.00 \pm 10.34$ & $\mathrm{ab}$ \\
\hline Heart girth (am) & $74.00 \pm 6.20$ & $69.67 \pm 7.39$ & $b$ & $75.60 \pm 5.72$ & $a b$ & $79.00 \pm 12.79$ & a \\
\hline Height at withers (cm) & $77.22 \pm 5.38$ & $78.00 \pm 4.35$ & & $75.40 \pm 3.37$ & & $84.00 \pm 7.54$ & \\
\hline Body weight $(\mathrm{kg})$ & $49.33 \pm 7.81$ & $53.00 \pm 8.24$ & $a b$ & $45.80 \pm 6.30$ & $b$ & $56.00 \pm 14.23$ & a \\
\hline
\end{tabular}

Means within rows with different superscripts are significantly different $(P<0.05)$

The Effects of IGF 1 gene polymorphisms on morphometric traits of the Yankasa sheep are presented on Table 4. IGF 1 gene polymorphisms did not significantly $(P<0.05)$ affect most morphometric traits of the Yankasa sheep except height at withers. The genotype $A B$ had higher ( $P$
$<0.05)$ height at withers $(71.77 \mathrm{~cm})$ than $A A$ $(53.50 \mathrm{~cm})$. This might indicate that the $A B$ genotypes were taller than the others. However, the three genotypes $A A, A B$ and $B B$ did not differ significantly $(P>0.05)$ for body length, heart girth and body weight.

Table 4: Effects of IGF 1 gene polymorphisms on morphometric traits of the Yankasa sheep

\begin{tabular}{llccc} 
& \multicolumn{3}{c}{ Genotype } \\
Morphometric traits & Overall mean & AA & AB & BB \\
\hline Body Length $(\mathbf{c m})$ & $69.68 \pm 5.37$ & $58.00 \pm 6.62$ & $70.94 \pm 2.27$ & $70.00 \pm 3.82$ \\
Heart girth $(\mathbf{c m})$ & $66.96 \pm 5.33$ & $55.50 \pm 7.56$ & $68.53 \pm 2.59$ & $66.33 \pm 4.37$ \\
Height at withers $(\mathbf{c m})$ & $68.72 \pm 4.93$ & $53.50 \pm 7.66$ b & $71.77 \pm 2.62$ a & $65.17 \pm 4.42$ ab \\
Body weight $(\mathbf{k g})$ & $42.44 \pm 4.05$ & $38.00 \pm 6.89$ & $43.47 \pm 2.36$ & $41.00 \pm 3.98$ \\
\hline
\end{tabular}

Means within rows with different superscripts are significantly different $(P<0.05)$

The Effects of IGF 1 gene polymorphisms on morphometric traits of the Uda sheep are presented on Table 5. IGF 1 gene polymorphisms did not significantly $(P<0.05)$ affect any morphometric traits of the Uda sheep. The three genotypes $A A, A B$ and $B B$ did not differ significantly $(P>0.05)$ for body length, heart girth, height at withers and body weight. Nazari et. al. (2016) also reported non-significant effect of IGF 1 gene polymorphisms on early growth traits of Iranian Zandi sheep. Similarly, Hajihosseinlo et. al. (2013) earlier reported nonsignificant effect of IGF 1 gene polymorphisms on height at withers of Makui sheep in Iran. The authors however observed significantly $(P<$ 0.05) higher body length measurements for $B B$ genotype compared to $A A$ and $A B$. 


\begin{tabular}{llccc}
\hline & & \multicolumn{3}{c}{ Genotype } \\
Morphometric traits & Overall mean & AA & AB & BB \\
\hline Body Length $(\mathbf{m})$ & $71.35 \pm 7.56$ & $74.00 \pm 10.47$ & $71.95 \pm 9.06$ & $70.00 \pm 6.85$ \\
Heart girth $(\mathbf{c m})$ & $61.78 \pm 6.42$ & $63.33 \pm 9.28$ & $63.75 \pm 8.45$ & $60.00 \pm 6.07$ \\
Height at withers (am) & $67.51 \pm 8.01$ & $72.00 \pm 9.62$ & $67.75 \pm 8.51$ & $65.57 \pm 6.43$ \\
Body weight $(\mathbf{k g})$ & $41.93 \pm 5.00$ & $44.60 \pm 6.21$ & $43.50 \pm 5.38$ & $39.86 \pm 4.07$ \\
\hline
\end{tabular}

Means within rows with different superscripts are significantly different $(P<0.05)$

\section{Conclusion}

The IGF 1 gene was $100 \%$ polymorphic in Balami, Yankasa and Uda sheep breeds. Significant association was established between IGF 1 genotype and some morphometric traits in Balami and Yankasa sheep. This might indicate that it could be used as a genetic marker for such traits.

\section{References}

Adams, L. J. and Maddox J. F. (1994). A dinucleotide repeat polymorphisms in the ovine insulin-like growth factor-1 gene 5 ' flanking region. Anim. Genet. 25(1): 61 - 69.

Akinyemi, M. O. and Salako, A. E. (2012). Genetic relationship among Nigerian indigenous sheep population using blood protein polymorphisms. Agric. Sci. Tech. 4 (2): 107 - 112

Andrade, P. C, Grossi, D. A., Paz, C. C., Alencar, M. M., Regitano, L. C. and Munari, D. P. (2008). Association of an insulin-like growth factor-1 gene microsatellite with phenotypic variation and estimated breeding values of growth traits in Canchim cattle. Anim. Genet. 39: 480 - 485.

Bahrami, A., Behzadi, S. H., Miraei-Ashtiani, S. R., Roh, S. G. and Katoh, K. (2013). Genetic polymorphisms and protein structures in growth hormone, growth hormone receptor, ghrelin, insulin-like growth factor 1 and leptin in Mehraban sheep. Genetics 527(1):397 - 404.

Bourn, D., Milligan, K. and Wint, W. (1986). Tsetse, tryponosomiasis and cattle in changing environment. In R. von Kaufman, Chater. S. and Blench, R. (Eds). Proceedings of the $2^{\text {nd }}$ ILCA/NAPRI Symposium, Kaduna, Nigeria, $29^{\text {th }}$ October - $2^{\text {nd }}$ November, 1984, pp. 85.
Curi R. A., Oliveira H. N., Silveira A. C. and Lopes C. R. (2004). Effects of polymorphic microsatellites in the regulatory region of IGF-I and GHR on growth and carcass traits in beef cattle. Anim. Genet. 6:58 - 62.

Echternkamp, S. E., Roberts, A. J., Lunstra, D. D., Wise, T. and Spicer, L. J. (2000). Ovarian follicular development in cattle selected for twin ovulations and births. J. Anim. Sci. 82: 459 - 471

Hajihosseinlo, A., Hashemi, A., RazaviSheshdeh, S. A. and Pirany, N. (2013). Association of the polymorphisms in the $5^{\prime}$ flanking region of the ovine IGF-I gene with growth and development traits in Makui sheep of Iran. Eur. J. Zool. Res. 2 (4):19 - 24.

He, J. N., Zhang, B. Y., Chu, M. X., Wang, P. Q., Feng, T., Cao, G. L., Di, R. Fang, L. Huang, D. W., Tang, Q. Q and Li, N. (2012). Polymorphisms of insulin-like growth factor 1 gene and its association with litter size in Small Tail Han sheep. Mol. Biol. Rep. 39 (10): 9801 - 07.

Honarvar, M., Moradi-Shahrebabak, M., Sadeghi, H., Behzadi, S. H. and Mohamadabadi, M. R. (2012). Study of the polymorphisms at the 5 'flanking region of the ovine IGFI Gene and its association with carcass traits in Zel (tailed) and Lori-Bakhtiari (fat-tailed) breed sheep using PCR-SSCP. J. Agric. Biotechnol. 4(2): 71 - 82.

Kim, E. S., Shi, X., Cobanoglu, O., Weigel, K., Berger, P. J. and Kirkpatrick, B. W. (2009). Refined mapping of twinning-rate quantitative trait loci on bovine chromosome 5 and analysis of insulin-like growth factor-I as a positional candidate gene. J. Anim. Sci. 87:835 - 843. 
Li, C., Basarab, J., Snelling, W. M., Benkel, B., Murdoch, B., Hansen, C. and Moore, S. S. (2004). Assessment of positional candidate genes myf5 and IGF-I for growth on bovine chromosome 5 in commercial lines of Bos taurus. J. Anim. Sci. 82: $1-7$.

Machado, M. B. B., Alencar, M. M., Pereira, A. P., Oliveira, H. O., Casas, E., Coutinho, L. L. and Regitano, L. C. A. (2003). QTL affecting body weight in a candidate region of cattle chromosome 5. Genet. Mol. Biol. 26: 259 - 265.

Maheswaran, M. (2014). Molecular Markers: History, Features and Applications". Advanced Biotech. IPGRI, Rome, Italy and Institute for Genetic Diversity, Ithaca, New York, USA. Pp. 1 8.

Nazari, F., Noshary, A and Hemati, B. (2016). Association between Insulin like Growth Factor I polymorphisms and early growth traits of Iranian Zandi sheep, found polymerase chain Reaction Restriction Fragment Length Polymorphisms (PCR-RFLP). Iran. J. Appl. Anim. Sci. 6(3):665669.

Rashidi, A., Mokhtari, M. S., Sati Jahanshani, A. and Mohammad Abadi, M. R. (2008) Genetic parameter estimates of pre-weaning growth traits in Kermain sheep. Small Ruminant Res. 74: $165-171$.
Rothschild, M. F., and Soller, M. (1997). Candidate gene analysis to detect traits of economic importance in domestic livestock. Probe 8: 13 - 20.

Sakowaski, S. Schuyler, A. and Feldman, E. (2009). Insulin-like growth factor-1 for the treatment of amyotrophic lateral sclerosis. Amyotroph. Lateral Scler. 10(2): 63 - 73.

Sattler, F. (2013). Growth hormone in the aging male. Best Pract. Res. Clin. Endocrinol. Metab. 27(4): $541-555$

Sirotkin, A. V., Mertin, D., Suvegova, K., Makarevich, A. V. and Mikulova, E. (2003). Effect of $\mathrm{GH}$ and IGF-1 treatment on reproduction, growth and plasma hormone spacing concentrations in domestic Nutria (Myocastor coypus). Gen. Comp. Endocrinol. 131: 296 - 301.

Velazquez, M. A., Newman, M., Christine, M. F., Cripps, P. Crowe, M. A., Smith, R. F. and Dobson, $H$. (2005). The usefulness of a single measurement of insulin-like growth factor-1 as a predictor of embryo yield and pregnancy rates in a bovine MOET program. Theriogenology 64:1877- 1994.

Yunusa, A. J., Salako, A. E. and Oladejo, O. A. (2013). Principal Component Analysis of the morphostructure of Uda and Balami sheep of Nigeria. Int. Res. J. Agric. Sci. 1 (3): 45 - 51 